\title{
Takayasus's Arteritis in Pregnancy. Case Report and Literature Review
}

\author{
Plínio da Cunha Leal 1 , Fernanda Fabrízia Martins Silveira ${ }^{1}$, Eduardo Jun Sadatsune ${ }^{1}$, Jefferson Clivatti ${ }^{2}$, \\ Américo Masafuni Yamashita ${ }^{3}$
}

\begin{abstract}
Summary: Leal PC, Silveira FFM, Sadatsune EJ, Clivatti J, Yamashita AM - Takayasus's Arteritis in Pregnancy. Case Report and Literature Review.

Background and objectives: Takayasus's Arteritis (TA) is a chronic, inflammatory, progressive, idiopathic disease that causes narrowing, occlusion, and aneurysms of systemic and pulmonary arteries affecting especially the aorta and its branches. During pregnancy, one should pay special attention to these patients. The objective of this report was to present the peripartum anesthetic care of a patient with TA and a review of the literature.
\end{abstract}

Case report: This is a 31-year old gravida who underwent exchange of the aortic arch and placement of a metallic aortic valve for TA four years ago. She had no complications during pregnancy, and she was admitted at 34 weeks of pregnancy for anticoagulation management. Elective cesarean section was performed at 39 weeks with continuous epidural anesthesia. Fractionated doses of local anesthetic were administered to guarantee slow installation of the blockade. The patient remained hemodynamically stable and was transferred to the ICU in the postoperative period.

Conclusions: Several complications can affect gravidas with TA. Careful patient evaluation, treatment of TA complications, and anestheticsurgical planning are fundamental. Maintenance of perfusion is the main concern in these patients, and neuraxial blocks may be used without harming the mother and fetus. In patients with compensated TA complications, monitoring does not differ from that routinely used in cesarean sections. Continuous epidural anesthesia with slow installation maintains hemodynamic stability and allows monitoring cerebral perfusion through the level of consciousness. To avoid postoperative hypoperfusion or hypertensive complications patients should be monitored in an intensive or semi-intensive care unit for 24 hours.

Keywords: Takayasu Arteritis; Anesthesia, Obstetrical; Cesarean Section; Heart Valve Diseases.

\section{INTRODUCTION}

Takayasu Arteritis (TA) is a chronic, inflammatory, progressive, idiopathic disease that causes narrowing, occlusion, and aneurysms of systemic and pulmonary arteries affecting mainly the aorta and its branches ${ }^{1,2}$.

It affects females in the reproductive years accounting for almost $80 \%$ of the cases ${ }^{3}$. The evolution of the disease is not affected during pregnancy; however, one should be careful with the peripartum conduction of these patients, since they can develop complications such as hypertension, multiple or-

Received from Universidade Federal de São Paulo/Escola Paulista de Medicina (UNIFESP/ EPM), São Paulo, SP, Brazil.

1. Senior Resident of the CET/SBA Disciplina de Anestesiologia, Dor e Terapia Intensiva of EPM/UNIFESP

2. Anesthesiologist, Preceptor of Anesthesiology Residents of the Disciplina de Anestesiologia, Dor e Terapia Intensiva of EPM/UNIFESP

3. MSc., Assistant Professor of the Disciplina de Anestesiologia, Dor e Terapia Intensiva of EPM/UNIFESP

Submitted on December 03, 2010

Approved on January 17, 2011.

Correspondence to:

Dr. Plínio da Cunha Leal

Avenida Onze de Junho - 1.134, apartamento 24

Vila Clementino

04041004 - São Paulo, SP, Brazil

E-mail: pliniocunhaleal@ hotmail.com gan dysfunction, stenosis that hinder regional blood flow and therefore monitoring of blood pressure, and restricted intrauterine growth ${ }^{4}$. The objective of the present study was to describe the management of a gravida with TA, its implications on anesthetic technique, and review the literature of the subject.

\section{CASE REPORT}

This is a 31-year old gravida, $168 \mathrm{~cm}$, gesta IV para III, with a history of three vaginal deliveries without intercurrence. At the age of 26 years she developed acute pulmonary edema associated with severe aortic insufficiency with important ectasia of the ascending aortic arch. Surgical correction was performed with placement of a Dacron prosthesis in the aortic arch and metallic prosthesis in the aortic valve. Analysis of the surgical specimens confirmed the diagnosis of TA.

During pregnancy the patient was treated with atenolol $25 \mathrm{mg}$ every 12 hours for control of hypertension; prednisone $40 \mathrm{mg}$ day $^{-1}$; non-fractionated heparin 5,000 IU, subcutaneously every 12 hours until the $12^{\text {th }}$ week; and sodium warfarin $2.5 \mathrm{mg}$ in alternate days after this period.

Around the $24^{\text {th }}$ week the patient developed precordial squeezing pain without irradiation and without triggering factors, without dyspnea or any other symptoms that improved 
with rest. On physical exam, left upper limb pulse was absent, and she had a murmur in the epigastric region without any other changes. Supplementary investigation ruled out myocardial infarction or other complications of TA. Doppler ultrasound of carotid and vertebral arteries did not show the presence of stenosis or aneurysms.

She had no complications during pregnancy, and the patient was admitted at the $34^{\text {th }}$ week to substitute sodium warfarin by enoxaparin $80 \mathrm{mg}$ SQ every 12 hours, since she had no conditions to use it at home. Echocardiogram showed an ejection fraction of $71 \%$, mild mitral and tricuspid insufficiency, minimal aortic insufficiencies, increased velocity of transvalvular aortic flow, maximum calculated systolic gradient of $33 \mathrm{mmHg}$, and tubular prosthesis in the ascending aorta.

It was not possible to perform a thoracoabdominal angioMRI to complement the investigation of other vessels involvement because the model of the valvular prosthesis used by the patient was not known. Since the patient had a murmur in the epigastric region, and it was not possible to rule out the presence of an abdominal aortic aneurysm, she was scheduled for a cesarean section at 39 weeks of pregnancy. Anticoagulation was changed to continuous infusion of heparin 12 hours before the cesarean section. On the scheduled date the patient was asymptomatic after an 8-hour fasting period. Her last laboratorial exams were: $\mathrm{Hb} 12.0 \mathrm{mg} \cdot \mathrm{dL}^{-1}$; platelets 230,000. $\mathrm{mm}^{-3}$; creatinine $0.7 \mathrm{mg} \cdot \mathrm{dL}^{-1} ; \mathrm{Na}^{+} 136 \mathrm{mg} \cdot \mathrm{dL}^{-1} ; \mathrm{K}^{+}$ $4.7 \mathrm{mg} . \mathrm{dL}^{-1}$; $\mathrm{Ca}^{++} 1.3 \mathrm{mmol} . \mathrm{L}^{-1}$; glucose $92 \mathrm{mg} . \mathrm{dL}^{-1}$; APTT 26 seconds and a ratio of 0.98 .

An 18G caliber Teflon catheter was used for venous cannulation in the right forearm, and $1,000 \mathrm{~mL}$ of Ringer's lactate were infused intraoperatively. A dose of $25 \mathrm{mg}$ of intravenous hydrocortisone was administered before anesthetic induction. Monitoring consisted of pulse oximetry on right upper limb, non-invasive blood pressure on left upper limb, 5-lead electrocardiogram, and diuresis.

Continuous epidural anesthesia was the technique chosen. With the patient in the sitting position, a 16G Tuohy needle was introduced in the $L_{1}-L_{2}$ space by the loss of resistance technique, and a catheter was introduced. The patient was placed in dorsal decubitus with her uterus deviated to the left side. Fractionated doses of $0.5 \%$ bupivacaine with vasoconstrictor associated with $100 \mu \mathrm{g}$ of fentanyl and $1 \mathrm{mg}$ of morphine were administered through the epidural catheter to guarantee slow installation of the blockade. Bupivacaine $75 \mathrm{mg}$ was administered until the sensorial blockade reached T4. The time of installation of the blockade was 20 minutes. Systolic blood pressure ranged from 90 to $110 \mathrm{mmHg}$, diastolic blood pressure from 60 to $70 \mathrm{mmHg}$, and heart rate between 60 and 80 bpm without vasopressor. Estimated blood loss was approximately $1,000 \mathrm{~mL}$. Urine output was $1 \mathrm{~mL} \cdot \mathrm{kg}^{-1} \cdot \mathrm{h}^{-1}$. The newborn weighed $2.800 \mathrm{~kg}$ with an Apgar of 9/9. An additional $25 \mathrm{mg}$ of bupivacaine was needed during the cesarean section.

After the surgical procedure the patient was transferred to the ICU where she remained for 24 hours without complications. Anticoagulation with enoxaparin $60 \mathrm{mg} \mathrm{SQ}$ every 12 hours was reintroduced 24 hours after the cesarean section.
Posteriorly, the dose of sodium warfarin was adjusted for an INR ratio of 2 to 3 . She was discharged from the hospital after 10 days.

\section{DISCUSSION}

Takayasu Arteritis was first described in 1908 by two Japanese ophthalmologists, Takayasu and Onishi, who observed retinopathy in the absence of peripheral pulses ${ }^{5}$. Although more common in Oriental women it is seen worldwide ${ }^{6}$. The cause is unknown, but it seems to be related to autoimmunity, sex hormones (more common in young females), and genetics (demonstrated by the predisposition of the human leukocyte antigen - HLA BW52) ${ }^{7}$.

Four types of Takayasu Arteritis can be identified: Type I (disease involving the aortic arch and its branches), type II (lesions restricted to descending thoracic aorta and abdominal aorta), type III (patients have characteristics of types I and II), and type IV (involvement of the pulmonary artery) ${ }^{8}$.

The disease can also be classified into stages according to the presence of major complications such as hypertension, retinopathy, aneurysms, and aortic insufficiency ${ }^{9}$. Stage I, no complications are observed; stage Ila, patients have only one of these complications; and stage Ilb, patients have only one of these complications, but the severe form; stage III, when more than one complication is present. The patient presented here was in stage II, but during pregnancy her hypertension was compensated and her aneurysm had been corrected.

Diagnosis is based on signs and symptoms, inflammatory markers, and arteriography demonstrating aortic stenosis and of its branches. However, the gold-standard for diagnosis is the biopsy of the vessel ${ }^{12}$.

Pregnancy does not interfere on disease progression, although hypertensive complications such as preeclampsia and exacerbation of chronic hypertension, and fetal complications such a restriction of intrauterine growth, abortion, and fetal death have been reported in $60 \%$ to $90 \%$ of the cases ${ }^{5}$. The high incidence of restricted uterine growth seems to be related to uncontrolled hypertension and aorta and iliac arteries involvement ${ }^{10}$. Arterial ultrasound Doppler, which quantifies the flow in the uterine arteries, is another way of evaluating fetal well-being and growth in patients with TA.

Few patients are asymptomatic and more than $60 \%$ have some kind of complication. Hypertension, caused by reduction in elasticity and narrowing of the aorta and its branches, besides abnormalities in the function of the aortic and carotid baroreceptors function, is the most common ${ }^{11}$. Occlusive and stenotic lesions might require revascularization by percutaneous angioplasty, use of endoprosthesis, or surgical correction ${ }^{13}$.

Patients should have a detailed pre-anesthetic evaluation. Participation of other specialties is fundamental for detection and treatment of disease complications. In the case presented here the disease was compensated with drug therapy, and lesions in the aortic arch and aortic valve had been corrected, but the patient did not have a recent arteriography or 
angio-MRI of large vessels, and the risk of a non-diagnosed abdominal aortic aneurysm influenced the path of delivery.

Treatment of TA involves the use of corticosteroids, the first line treatment for inflammatory activity as well as immunosuppressors including methotrexate and azathioprine. Chronic use of corticosteroids could lead to suppression of adrenal gland activity with inadequate release of endogenous corticosteroids in moments of stress, such as surgeries. Intraoperative corticosteroid supplementation for moderate risk surgeries such as abdominal surgeries should be done with intravenous hydrocortisone $25 \mathrm{mg}$ preoperatively, followed by 12.5-25 mg intravenously every 6-8 hours over the first 24-36 hours after surgery, as used in the case described here ${ }^{14,15}$.

Vaginal delivery could be indicated for patients in groups I and Ila, as long as epidural analgesia is used for pain relief, and delivery is abbreviated by the use of forceps especially in hypertensive patients ${ }^{16}$. In groups IIb and III, one should prefer cesarean section, since the increased blood volume and blood pressure observed during uterine contractions as well as the increased cardiac output observed during labor may lead to cardiac decompensation ${ }^{17}$. Although our patient was hemodynamically stable, she underwent cesarean section because she belonged to group III and she did not have additional supplementary investigation of the abdominal vessels.

In patients with compensated complications of TA, monitoring does not differ from that routinely used in cesarean sections, i.e., oximetry, cardioscope, blood pressure, and diuresis. In case of general anesthesia, capnography and cerebral monitoring should be used. Blood pressure monitoring can be difficult in patients with pulseless peripheral arteries. In most reported cases, it was possible to use the non-invasive technique $^{3}$. If there is a large difference in blood pressure in upper and lower limbs, a good alternative is monitoring both limbs. If there is a difference greater than $20 \mathrm{mmHg}$ between both upper limbs, both limbs should be monitored with non-invasive blood pressure. To evaluate limb perfusion a good alternative is to assess blood pressure in one limb and oximetry in the other; similar to what was done in the case presented here. Invasive blood pressure should be reserved for cases in which it was not possible to obtain non-invasive blood pressure, prolonged surgeries, and uncontrolled blood pressure, since complications of arterial catheterization are more common in patients with peripheral vasculopathies ${ }^{4}$.

Regional anesthesia is the technique of choice because it allows monitoring brain perfusion through the patient's level of consciousness. On continuous epidural fractionated doses of local anesthetic are administered and the level of the blockade can be slowly titrated to maintain hemodynamic stability by reducing the need of vasopressors. Double block with low doses of spinal local anesthetic to avoid sympathetic blockade and hemodynamic instability is an alternative to continuous epidural anesthesia ${ }^{18}$. However, injection of local anesthetic in the epidural catheter before spinal blockade may increase the spread the local anesthetic in CSF, nullifying the hemodynamic advantages of the technique. Hydration should be guided by patient's cardiovascular condition and it can be initiated at the time of blockade ${ }^{19}$.

Continuous epidural anesthesia with slow installation of the blockade was used to avoid hypotension and the administration of vasopressors, since there may be stenotic lesions that compromise organ perfusion, especially in patients without previous arteriography 20 .

In reviewing the literature published in 2008 , spinal anesthesia was performed in four patients (three cesarean sections and one abortion), epidural anesthesia in five patients (five cesarean sections), combined anesthesia in one patient (cesarean section), and general anesthesia in two patients (two cesarean sections). In this same article, the authors reported five cases, three of epidural anesthesia and two of combined anesthesia. According to the authors, combined anesthesia can be a good alternative to epidural anesthesia, but with greater need of fluid replacement and vasopressors ${ }^{4}$.

Patients with metallic valvular prosthesis should be maintained anticoagulated during pregnancy. The choice of medication should take into account the probable due date and reversibility of the method. Both vaginal delivery and cesarean section in an anticoagulated patient can lead to difficult bleeding control. Heparin should be discontinued 4 to 6 hours before anesthesia, and it can be reversed with protamine if the gravida goes into labor or in case of bleeding. Patients on prophylactic doses of enoxaparin should received their last dose 12 hours before anesthesia. In the case of therapeutic doses the drug should be discontinued 24 hours before anesthesia ${ }^{21}$.

Preventing hypertension is as important as the prevention of hypotension. Induction of general anesthesia should be very careful to avoid a hypertensive crisis during tracheal intubation. Patients may develop hemorrhagic complications especially in the brain. In case when general anesthesia is necessary brain monitoring is important. Options include electroencephalography ${ }^{22}$ or transcranial Doppler ${ }^{23}$, but there is no consensus on which is the best method. There is only one reported case of brain ischemia in a TA patient who underwent general anesthesia for a pectoral flap to cover a defect of neck dissection ${ }^{24}$. Thus, relative indications of general anesthesia should be reviewed in these cases, since regional anesthesia allows direct monitoring of brain activity.

To avoid postoperative hypoperfusion of organs and hypertensive complications the patient should remain monitored in the intensive or semi-intensive care unit for 24 hours.

Gravidas with TA may develop several complications. Careful patient evaluation, treatment of TA complications, and anesthetic-surgical planning are essential. Maintenance of perfusion is the main concern in these patients, and neuraxial anesthesia may be used without injury to mother or newborn. 


\section{REFERÊNCIAS / REFERENCES}

01. Beilin $\mathrm{Y}$, Bernstein $\mathrm{H}$ - Successful epidural anaesthesia for a patient with Takayasu's arteritis presenting for Caesarean section. Can J Anaesth, 1993;40:64-66.

02. Ishikawa K, Matsumura S - Occlusive thromboaortopathy (Takayasu's disease) and pregnancy. Clinical course and management of 33 pregnancies and deliveries. Am J Cardiol, 1982;50:1293-1300.

03. Ioscovich A, Gislason R, Fadeev A et al. - Peripartum anesthetic management of patients with Takayasu's arteritis: case series and review. Int J Obstet Anesth, 2008;17:358-364.

04. Kathirvel S, Chavan S, Arya VK et al. - Anesthetic management of patients with Takayasu's arteritis: a case series and review. Anesth Analg, 2001;93:60-65.

05. Matsumura A, Moriwaki R, Numano F - Pregnancy in Takayasu arteritis from the view of internal medicine. Heart Vessels, 1992;7(Suppl):120124.

06. Domingo RT, Maramba TP, Torres LF et al. - Acquired aorto-arteritis. A worldwide vascular entity. Arch Surg, 1967;95:780-790.

07. Wilke WS - Large vessel vasculitis (giant cell arteritis, Takayasu arteritis). Baillieres Clin Rheumatol, 1997;11:285-313.

08. Lupi-Herrera E, Sanchez-Torres G, Marcushamer J et al. - Takayasu's arteritis. Clinical study of 107 cases. Am Heart J, 1977;93:94-103.

09. Ishikawa K - Natural history and classification of occlusive thromboaortopathy (Takayasu's disease). Circulation, 1978;57:27-35.

10. Mahmood T, Dewart PJ, Ralston AJ et al. - Three successive pregnancies in a patient with Takayasu's arteritis. J Obstet Gynaecol, 1997; 17:52-54

11. Sharma BK, Sagar S, Singh AP et al. - Takayasu arteritis in India. Heart Vessels, 1992;7(suppl):37-43.

12. Kerr GS, Hallahan CW, Giordano J et al. - Takayasu arteritis. Ann Intern Med, 1994;120:919-929.

13. Liang $P$, Hoffman GS - Advances in the medical and surgical treatment of Takayasu arteritis. Curr Opin Rheumatol, 2005;17:16-24.

14. Salem M, Tainsh RE Jr., Bromberg J et al. - Perioperative glucocorticoid coverage. A reassessment 42 years after emergence of a problem. Ann Surg, 1994;219:416-425.

15. Coursin DB, Wood KE - Corticosteroid supplementation for adrenal insufficiency. JAMA, 2002;287:236-240.

16. Wong VC, Wang RY, Tse TF - Pregnancy and Takayasu's disease. Am J Med, 1983;75: 597-601.

17. Henderson K, Fludder P - Epidural anaesthesia for caesarean section in a patient with severe Takayasu's disease. $\mathrm{Br} J$ Anaesth, 1999;83:956-959.

18. Choi DH, Kim JA, Chung IS - Comparison of combined spinal epidural anesthesia and epidural anesthesia for caesarean section. Acta Anaesthesiol Scand, 2000;44:214-219.
19. Banerjee A, Stocche RM, Angle P et al. - Preload or coload for spinal anesthesia for elective Cesarean delivery: a meta-analysis. Can J Anaesth, 2009;57:24-31.

20. Hauth JC, Cunningham FG, Young BK - Takayasu's syndrome in pregnancy. Obstet Gynecol, 1977;50:373-375.

21. Thornton P, Douglas J - Coagulation in pregnancy. Best Pract Res Clin Obstet Gynaecol, 2010;24:339-352.

22. Clark AG, al-Qatari M - Anaesthesia for Caesarean section in Takayasu's disease. Can J Anaesth, 1998;45:377-379.

23. Kawaguchi M, Ohsumi H, Nakajima T et al. - Intra-operative monitoring of cerebral haemodynamics in a patient with Takayasu's arteritis. Anaesthesia, 1993;48:496-498.

24. Fawcett WJ, Razis PA, Berwick EP - Post-operative cerebral infarction and Takayasu's disease. Eur J Anaesthesiol, 1993;10:33-35.

Resumen: Leal PC, Silveira FFM, Sadatsune EJ, Clivatti J, Yamashita AM - Arteritis de Takayasu en el Embarazo. Relato de Caso y Revisión de la Literatura.

Justificativa y objetivos: La Artritis de Takayasu (AT), es una enfermedad idiopática, crónica, inflamatoria y progresiva, que causa el estrechamiento, la oclusión y los aneurismas de las arterias sistémicas y pulmonares, afectando principalmente a la aorta y a sus ramas. Durante el embarazo, debemos estar atentos al seguimiento de esas pacientes. El objetivo fue relatar un caso de seguimiento anestésico periparto de una paciente con AT y hacer una revisión de la literatura.

Relato de Caso: Embarazada de 31 años con cambio del arco aórtico y prótesis metálica en válvula aórtica por AT hacía 4 años. El embarazo continuó sin complicaciones y la paciente fue ingresada con 34 semanas para la adecuación de la anticoagulación. Se realizó la cesárea electiva con 39 semanas de embarazo con anestesia epidural continua. Se administraron dosis fraccionadas de anestésico local para garantizar la instalación lenta del bloqueo. La paciente permaneció estable hemodinámicamente y fue derivada al postoperatorio en la $\mathrm{UCl}$.

Conclusiones: Muchas complicaciones pueden sobrevenir en la embarazada con AT. La evaluación cuidadosa de la paciente, el tratamiento de las complicaciones de la AT y la planificación anestésica quirúrgica son fundamentales. El mantenimiento de la perfusión orgánica es la principal preocupación en esas pacientes, y los bloqueos neuroaxiales pueden ser utilizados sin miedo de perjudicar a la madre o al recién nacido. En la paciente con las complicaciones de la AT compensadas, la monitorización no es diferente de la utilizada como rutina en cesáreas. La anestesia epidural continua de instalación lenta, mantiene la estabilidad hemodinámica y permite monitorizar la perfusión cerebral a través del nivel de conciencia de la embarazada. Para evitar la hipoperfusión orgánica o las complicaciones hipertensivas en el postoperatorio, la paciente debe permanecer monitorizada en una unidad de cuidados intensivos o semi-intensivos durante 24 horas.

Descriptores: ANESTESIA: Obstétrica; CIRUGÍA: Cesárea; ENFERMEDAD: Cardáca, Vascular. 